\title{
Biosurfactants: Production and potential application in insect pest management
}

\author{
Tariku Tesfaye Edosa, Yong Hun Jo, Maryam Keshavarz and Yeon Soo Han* \\ Division of Plant Biotechnology, Institute of Environmentally-Friendly Agriculture (IEFA), \\ College of Agriculture and Life Sciences, Chonnam National University, \\ Gwangju 61186, Republic of Korea.
}

\begin{abstract}
Biosurfactants are amphipathic surface-active molecules produced by bacteria, fungi, and yeast. Owing to their low toxicity, high degree of biodegradability, optimal activity at extreme environmental conditions, and environmental friendly nature, biosurfactants have received attention in pest management. Most recently, the insecticidal activities of the biosurfactants obtained from different bacterial species have been reported. Therefore, considering the role of biosurfactants in novel insecticide production and environmentally safe insect pest management, we reviewed the isolation and identification of the biosurfactant-producing bacteria, the production methods of biosurfactants, and their potential applications in insect pest management, as well as delineated the possible future research areas. Finally, we concluded that, in the near future, biosurfactants will be the green pesticides that will replace the synthetic pesticides, and thus, for the discovery of novel insecticides, biochemical and molecular approaches, such as genomic and transcriptomic studies, are appreciable.
\end{abstract}

KEYWORDS: Bacillus, biosurfactant, biocides, biocontrol, bioprocessing, peptides.

\section{Introduction}

Biosurfactants are the surface-active biomolecules produced by bacteria, fungi, and yeast [1].

\footnotetext{
*Corresponding author: hanys@chonnam.ac.kr
}

Basically, these microorganisms produce different biosurfactants for various purposes; for instance, rhamnolipids increase the solubility of hydrophobic hydrocarbons [2], cause changes in microbial surface properties [3], and enhance the bioavailability of potential hydrophobic carbon sources [4]. Unlike the chemically synthesized surfactants, biosurfactants are generally categorized based on their microbial origin and chemical composition [5]. Chemically, biosurfactants are categorized into glycolipids (rhamnolipids) [6], trehalolipids [7], sophorolipids [8], lipopeptides and lipoproteins (surfactin, lichenysin), fatty acids, phospholipids and neutral lipids [8], polymeric, and particulate biosurfactants [9]. Owing to their safe properties such as, low toxicity [10], high degree of biodegradability [11], high foaming capacity [12], and optimal activity at extreme environmental conditions [13], biosurfactants have recently received attention for their different applications in various fields (food industry, removal of oil and petroleum contamination, bioremediation of toxic pollutants and biopesticides). Currently, the interest in the use of biosurfactants as biopesticides has been growing fast [14-17] because of their environment-friendly characteristics and high degree of degradability. Thus, to reduce the adverse effects of synthetic pesticides on the environment and human health, biosurfactants could be one of the promising alternative options in the management of agricultural pests. Hence, this review mainly emphasizes on the contribution of biosurfactants in the management of agricultural insect pests, production and application of biosurfactants, and the way forward. 


\section{History of biosurfactants as biopesticides}

Insecticides have a long history in insect pest control. Synthetic surfactants are popularly used as adjuvant, emulsifying, dispersing, spreading and wetting agents and enhance the efficiency of pesticides. As a result, they are highly used in several pesticide-manufacturing industries [18]. However, these synthetic surfactants are nondegradable and accumulate in soil and ground water, as well as on agricultural products [19]. As a result, they cause adverse effects on the environment and humans. Alternatively, different bacterial and fungal species have recently been reported to produce biosurfactants [16, 17, 20, 21]. These biosurfactants have well known applications in the food industry and bioremediation of toxic pollutants, and therefore, have recently received attention in the pesticide industry and pest control [18, 22-24].

\section{Types of biosurfactants}

Biosurfactants are classified based on their microbial origin and chemical composition [5]. Originally, biosurfactants are naturally produced by bacteria, fungi, and/or yeast. However, bacterial species are well known for producing different biosurfactants, with Pseudomonas being the dominant genus in biosurfactant production [1]. The Bacillus species, which is the most commonly known bacteria used in insect pest management, predominantly produces lipopeptides, lichenysin, surfactin, lipid protein complexes, and subtilisin [25-29]. Chemically, they are categorized into glycolipids, lipopeptides and lipoproteins, fatty acids, phospholipids and neutral lipids, polymeric biosurfactants, and particulate biosurfactants. For easy understanding, [30], these biosurfactants are grouped into two types, based on their molecular weights: low- and high-molecular weight biosurfactants.

\subsection{High-molecular weight biosurfactants}

High-molecular weight biosurfactants are produced by a number of diverse bacterial species and are generally termed as polymeric biosurfactants, which consist of lipoproteins, proteins, polysaccharides, lipopolysaccharides or complexes [31, 32]. The Acinetobacter species has been identified as the bacterial species producing most high-molecular weight biosurfactants (Table 1).

\subsection{Low-molecular weight biosurfactants}

Low-molecular weight biosurfactants include glycolipids, lipopeptides and lipoproteins, fatty acids, phospholipids, and neutral lipids. The major role of these surfactants is to increase the surface

Table 1. High-molecular weight biosurfactants, their chemical compositions and origins.

\begin{tabular}{|l|l|l|c|}
\hline Biosurfactant name & \multicolumn{1}{|c|}{ Components } & Origin & References \\
\hline Alasan & $\begin{array}{l}\text { Complex of an anionic } \\
\text { polysaccharide and a protein }\end{array}$ & Acinetobacter radioresistens & {$[33]$} \\
\hline Complex biopolymer & Proteins, carbohydrates, and lipids & Candida lipolytica IA 1055 & {$[34]$} \\
\hline $\begin{array}{l}\text { Non-dialyzable } \\
\text { bioemulsifier }\end{array}$ & $\begin{array}{l}\text { Complex of a protein, } \\
\text { polysaccharide, and lipid }\end{array}$ & Acinetobacter junii SC14 & {$[35]$} \\
\hline Alasan & $\begin{array}{l}\text { Complex of an anionic } \\
\text { polysaccharide and a protein }\end{array}$ & Acinetobacter radioresistens KA53 & {$[36,37]$} \\
\hline Biodispensan & Polysaccharide & Acinetobacter calcoaceticus & {$[38]$} \\
\hline Mannoprotein & Carbohydrate (mannose) and protein & Saccharomyces cerevisiae & {$[39]$} \\
\hline $\begin{array}{l}\text { Capsule } \\
\text { polysaccharide }\end{array}$ & Polysaccharide & Acinetobacter calcoaceticus BD4 & {$[40]$} \\
\hline Liposan & Carbohydrate and protein & Yeast (Yarrowia lipolytica) & {$[41]$} \\
\hline $\begin{array}{l}\text { Vesicles of } \\
\text { Acinetobacter }\end{array}$ & $\begin{array}{l}\text { Protein, phospholipid, and } \\
\text { lipopolysaccharide }\end{array}$ & Acinetobacter sp. strain HO1-N & {$[42]$} \\
\hline Emulsan & Lipopolysaccharide & $\begin{array}{l}\text { Acinetobacter calcoaceticus } \\
\text { RAG-1 ATCC 31012 }\end{array}$ & {$[43]$} \\
\hline
\end{tabular}


area of hydrophobic substrates, thereby enhancing the bioavailability of hydrophobic substrates through solubilization/desorption and regulating the attachment and removal of microorganisms from the surface [5]. The Pseudomonas and Bacillus species are widely known for producing lowmolecular weight biosurfactants. Some of these biosurfactants, their chemical components, and microbial origins are summarized in Table 2.

\section{Production strategies of biosurfactants}

Most of the biosurfactant-producing bacterial species are soil-inhabiting bacteria. Admittedly, the foremost step for biosurfactant production is the isolation and characterization of the target bacterial species (Fig. 1A). The chemical nature of a biosurfactant depends on the microbial species producing it. Thus, identifying the effective bacterial species has paramount importance in the production of biosurfactants for the purpose of insect pest control.

\subsection{Isolation and identification of biosurfactant- producing bacteria}

The source of a sample for bacterial isolation varies with the purpose of isolation. For instance, it could be from a traditional fermented food or from crude petroleum-oil-contaminated soil [60]. The isolation, taxonomic identification, and characterization of the biosurfactant-producing microorganism strains could be done by following the standard biochemical and morphological tests [61, 62]. Briefly, the sample is diluted and spread on the specific agar nutrient, and then incubated overnight at appropriate incubation temperature, which differs based on the targeted bacterial species. For example, if thermophilic bacterial species are targeted, an incubation temperature of $>50{ }^{\circ} \mathrm{C}$ is recommendable. Subsequently, the morphological tests, such as, colony size, shape and color; biochemical tests such as, Gram positive and negative; and molecular

Table 2. Low molecular weight biosurfactants, their chemical composition and origin.

\begin{tabular}{|l|l|l|c|}
\hline \multicolumn{1}{|c|}{ Biosurfactant name } & \multicolumn{1}{|c|}{ Components } & \multicolumn{1}{|c|}{ Origin } & Reference \\
\hline Rhamnolipids & Glycolipids & $\begin{array}{l}\text { Pseudomonas aeruginosa } \\
\text { Pseudomonas chlororaphis, } \\
\text { Serratia rubidaea }\end{array}$ & {$[44-46]$} \\
\hline Trehalolipids & Glycolipids & $\begin{array}{l}\text { Arthrobacter paraffineus } \\
\text { Rhodococcus erythropolis }\end{array}$ & {$[47,48]$} \\
\hline Sophorolipids & Glycolipids & $\begin{array}{l}\text { Torulopsis bombicola, } \text { T. apicola, } \\
\text { T. petrophilum, Candida bombicola, } \\
\text { C. antarctica, C. batistae, C. apicola, }\end{array}$ & {$[49-53]$} \\
\hline C. riodocensis, C. stellata, C. bogoriensis & \\
\hline Glucose lipids & Glycolipids & Alcanivorax borkumensis & {$[54]$} \\
\hline Surfactin & Lipopeptides & $\begin{array}{l}\text { Bacillus subtilis } \\
\text { B. amyloliquefaciens }\end{array}$ & {$[25,31,55]$} \\
\hline Lipopeptides & Lipopeptides & Bacillus licheniformis 86 & {$[28]$} \\
\hline Peptide lipids & Peptide lipids & Bacillus licheniformis & {$[27]$} \\
\hline Phosphatidylethanolamine & Fatty Acids, Phospholipids & Rhodococcus erythropolis & {$[56]$} \\
\hline Glycolipid bioemulsifier & $\begin{array}{l}\text { Disaccharides } \\
\text { Fatty acids }\end{array}$ & Rhodococcus erythropolis & {$[57]$} \\
\hline Corynomycolic acid & Fatty Acids & Corynebacterium diphtheriae & {$[59]$} \\
\hline Mannosylerythritol lipids & Glycolipids & $\begin{array}{l}\text { Pseudozyma antarctica, Pseudozyma } \\
\text { siamensis }\end{array}$ & \\
\hline
\end{tabular}



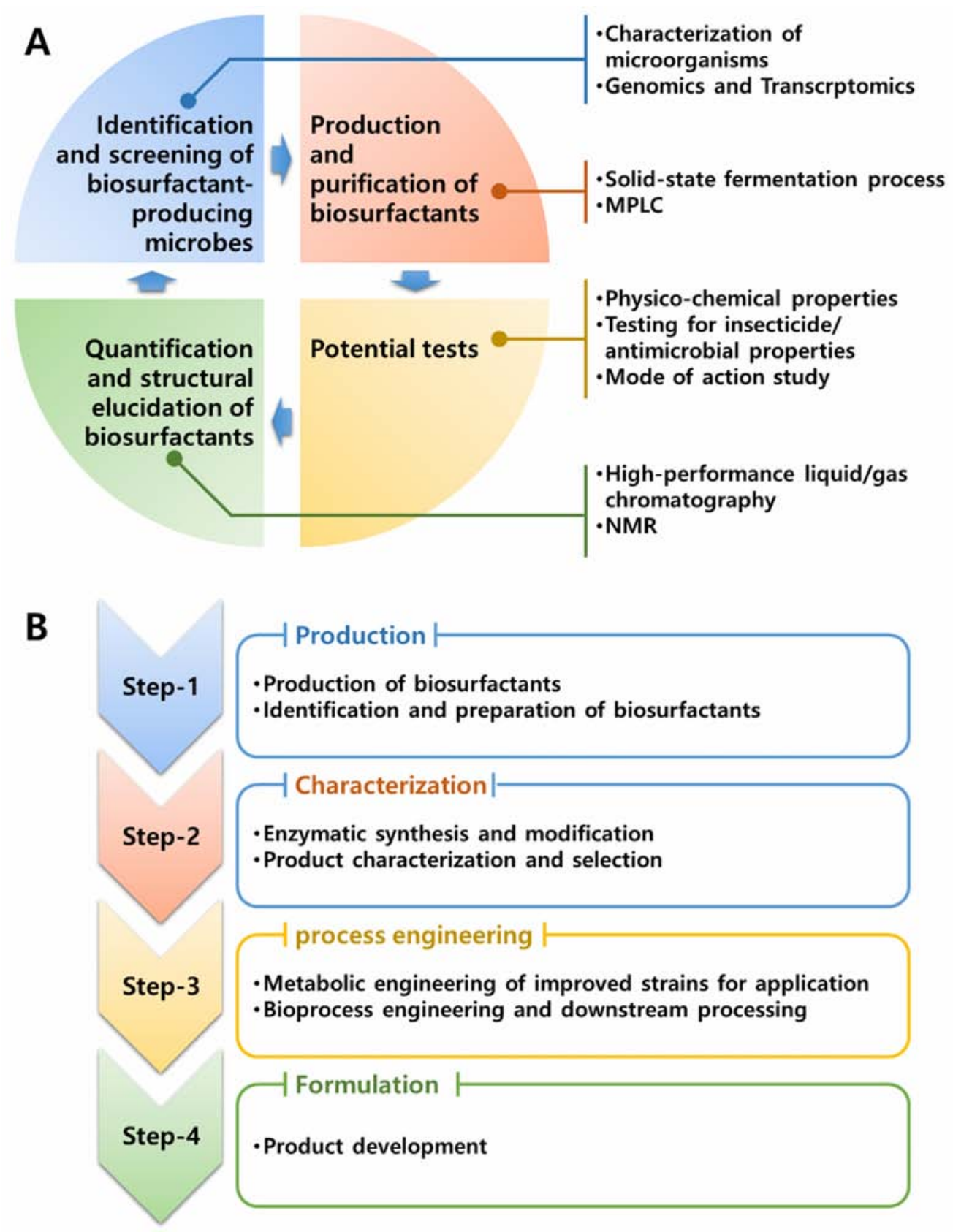

Fig. 1. Biosurfactant and novel bio-pesticide production strategies. A) Biosurfactant production and application strategies: The foremost step in the production of biosurfactants is the isolation, screening, and characterization of the biosurfactant-producing microbes using molecular (genomics and transcriptomic) and biochemical tests. Subsequently, biosurfactants are produced by solid-state fermentation and purified by middle pressure liquid chromatography (MPLC). The third step involves conducting insecticidal potential tests against target insects; this step also includes the mode of action study. Finally, the quantification and structural elucidation is carried out by high-performance liquid chromatography (HPLC) and nuclear magnetic resonance (NMR) methods, respectively, for the production of novel bio-pesticide. B) Novel bio-pesticide production Strategies: Step 1 (production) involves the identification of appropriate production methods, which are cost effective and produce quality biosurfactants. Step 2 (characterization) includes enzymatic synthesis and product characterization. Step 3 (process engineering) includes recovery, concentration, and purification of the samples. Step 4 (formulation) is the last step in which the product is developed and disseminated. 
identification tests like, polymerase chain reaction (PCR) amplification of the 16s rRNA gene and DNA sequencing could be employed as the identification and characterization tools. In general, the Bacillus species are well known for producing various types of biosurfactants [63-65].

\subsection{Production and identification of biosurfactants as biopesticides}

For experimental purposes, biosurfactants have been successfully produced in small quantities $[15,16$, $66]$. However, the successful production of a novel bio-pesticide from biosurfactants and its application relies mostly on the production processes and its quality [67] (Fig. 1B). These days, researchers have made an effort to improve the yield and quality of biosurfactants by using agricultural byproducts [15, 68, 69]. Besides cost effectiveness, the yield optimization process conditions have been extensively studied [60, 70, 71].

Solid-state and submerged fermentation are the common methods used in the production of biosurfactants for use as biopesticides [15, 60, 71]. However, the solid-state fermentation has several advantages over the submerged fermentation [72]. Consequently, this process has recently received considerable attention of researchers [71] and has potential applications in the production of microbial enzymes, bioinsecticides, secondary metabolites, and pharmaceuticals [73, 74].

The solid-state fermentation procedure was well developed for the extraction of biosurfactants [14, 15]. The industrial and agricultural byproducts could be used as carbon-source substrates. For example, banana peels, potato peels, chick-pea flour, corn bran, corn starch, millet, soya meal, barley flour, barley bran, rice flour, cornstarch, and orange peels [14] are carbon-rich substrates. These substrates need to be autoclaved at $120{ }^{\circ} \mathrm{C}$ for $30 \mathrm{~min}$. To these substrates, $\mathrm{Na}_{2} \mathrm{HPO}_{4}(6.0 \mathrm{~g} / \mathrm{l}), \mathrm{KH}_{2} \mathrm{PO}_{4}$ $(3.0 \mathrm{~g} / \mathrm{l}), \mathrm{NH}_{4} \mathrm{NO}_{3}(1.0 \mathrm{~g} / \mathrm{l}), \mathrm{NaCl}(1.0 \mathrm{~g} / \mathrm{l}), \mathrm{CaCl}_{2}$ $(0.014 \mathrm{~g} / \mathrm{l}), \mathrm{MgSO}_{4} .7 \mathrm{H}_{2} \mathrm{O}(0.245 \mathrm{~g} / \mathrm{l})$, thiamine$\mathrm{HCl}$ solution $(1.0 \mathrm{ml})$, and $1 \mathrm{ml}$ of a solution of micronutrients are added, mixed thoroughly, and autoclaved at $121{ }^{\circ} \mathrm{C}$ and 15 lbs pressure for $15 \mathrm{~min}$. Finally, $2 \mathrm{ml}$ of 24-h grown bacterial culture is inoculated into the prepared substrate under sterile conditions and incubated at appropriate temperature for 2 to 5 days [60]. The fermented bacterial culture is mixed with distilled water (1:5, $\mathrm{w} / \mathrm{v}$ ) and stirred on a magnetic stirrer for $30 \mathrm{~min}$ at room temperature, then centrifuged at $10,000 \times \mathrm{g}$ for $10 \mathrm{~min}$ at $4{ }^{\circ} \mathrm{C}$ to remove the insoluble material. The identification of biosurfactants from the crude mixture is carried out by performing the high-performance liquid chromatography (HPLC) and mass spectrometric analyses [62].

\section{Application of biosurfactants in insect pest control}

Biosurfactants are known to have low toxicity [10], high degree of biodegradability [11], and optimal activity at extreme environmental conditions [13]. These properties enable them to have wide applications in different fields.

For decades, microbial bioinsecticides have displayed the potential to control agricultural pests $[66,70]$ (Table 3). The Bacillus species are the most famous biosurfactant-producing bacteria. They produce broad-spectrum lipopeptides, including surfactin, iturin, bacillomycin, fengycin, and lichenysin [21, 62]. These are bioactive metabolites that cause hemolysis with potent larvicidal activity [75, 76]. Mnif and Ghribi (2015) [65] have intensively reviewed the role of Bacillus and Pseudomonas bacterial species-derived biopesticides in pest management.

Surfactin produced by Bacillus amyloliquefaciens G1 showed insecticidal potency against the green peach aphid, Myzus persicae, by affecting the aphid cuticles and inducing significant dehydration of the cuticle membrane to cause death [77]. Moreover, Khedher et al. (2015) [16] have reported the potential of B. amyloliquefaciens AG1 biosurfactant to control the Tuta absoluta larvae. The biosurfactant from this bacterium consists of lipopeptides and polyketides. This biosurfactant acts by binding to the receptors located in the brush-border membrane vesicles of the larvae. Similarly, Bacillus thuringiensis Vip3Aa16 and B. amyloliquefaciens AG1 biosurfactants showed insecticidal potency against Spodoptera littoralis. The histopathological examination of the treated larval midgut revealed the vacuolization, necrosis, and disintegration of the basement membrane [17].

Since 1900s, Bacillus subtilis, which is commonly found in the upper layers of the soil, has been used 
Table 3. Some of the biosurfactants used as biopesticides to control insects.

\begin{tabular}{|c|c|c|c|c|c|}
\hline Bacterial species & Biosurfactants & Composition & Activity & Insect & References \\
\hline \multirow{2}{*}{$\begin{array}{l}\text { Bacillus } \\
\text { amyloliquefaciens AG1 }\end{array}$} & Lipopeptides & $\begin{array}{l}\text { Surfactin, fengycin, } \\
\text { iturin, and } \\
\text { bacillomycin }\end{array}$ & \multirow{2}{*}{ Larvicidal } & \multirow{2}{*}{ Tuta absoluta } & \multirow{2}{*}{ [16] } \\
\hline & Polyketides & $\begin{array}{l}\text { Bacillaene, } \\
\text { macrolactin, and } \\
\text { difficidin }\end{array}$ & & & \\
\hline $\begin{array}{l}\text { Bacillus } \\
\text { amyloliquefaciens AG1 }\end{array}$ & Lipopeptides & $\begin{array}{l}\text { Surfactin, fengycin, } \\
\text { iturin, and } \\
\text { bacillomycin }\end{array}$ & Larvicidal & $\begin{array}{l}\text { Spodoptera } \\
\text { littoralis }\end{array}$ & [17] \\
\hline \multirow{2}{*}{ B. subtilis } & $\begin{array}{l}\text { Cyclic } \\
\text { lipopeptides }\end{array}$ & Surfactin & Larvicidal & Mosquito & {$[76,79,80]$} \\
\hline & Lipopeptide & Not given & Larvicidal & $\begin{array}{l}\text { Spodoptera } \\
\text { littoralis }\end{array}$ & [14] \\
\hline B. amyloliquefaciens & $\begin{array}{l}\text { Cyclic } \\
\text { lipopeptides }\end{array}$ & Not given & Pupicidal & & [76] \\
\hline $\begin{array}{l}\text { B. amyloliquefaciens } \\
\text { G1 }\end{array}$ & Lipopeptides & Surfactin & Insecticidal & Myzus persicae & [77] \\
\hline Bacillus thuringiensis & Not given & Cry3Aa toxin & Larvicidal & $\begin{array}{l}\text { Colorado potato } \\
\text { beetle }\end{array}$ & [81] \\
\hline Bacillus thuringiensis & Not given & Cry1Da toxin & Larvicidal & $\begin{array}{l}\text { Spodoptera } \\
\text { littoralis }\end{array}$ & [82] \\
\hline Bacillus subtilis & $\begin{array}{l}\text { Cyclic } \\
\text { lipopeptides }\end{array}$ & Surfactin & Larvicidal & Aedes aegypti L. & [83] \\
\hline
\end{tabular}

in human disease treatment. Presently, the biosurfactants of this species have been reported to have applications in insect pest control. B. subtilis SPB1 has been shown to produce a lipopeptide biosurfactant and insecticidal activity against the storage insect pests, carob moth, Ectomyelois ceratoniae [15]. The histopathological effects of $B$. subtilis SPB1 biosurfactant on E. ceratoniae midgut was also studied and showed vesicle formation in the apical region of cells and lysis and strong vacuolization of columnar cells. Similar histopathological effects were observed in Ephestia kuehniella [21], Spodoptera littoralis [70, 78], and Prays oleae [70].

From this, we can understand that the biosurfactants produced by Bacillus species target the midgut tissue to cause death of the treated insects; thus, the oral application method is the effective way of treatment. Furthermore, the molecular mechanisms of these biosurfactants need to be studied to fully understand their exact modes of action.
Additionally, the large-scale production of novel insecticides from this bacterial species needs further investigation.

\section{Conclusion and future direction}

Currently, biosurfactants have become one of the promising biopesticides in the management of insect pests. Though dozens of bacterial and fungi species have been reported to produce biosurfactants, only a few biosurfactants produced by the Bacillus species against insect pests have been well studied. Most of the exploited biosurfactants have been produced in small-scale in laboratories. Appreciating the efforts of some researchers, the mass production of these biosurfactants needs detailed study to produce the quality product. The targets of most biosurfactants and their modes of action in insects remain elusive. Therefore, the advanced biochemical and molecular approaches, such as genomic and transcriptomic studies, are crucial in studying their modes of action. This study will lead to the 
discovery of novel biopesticides. Hence, it can be concluded that, in the near future, biosurfactants will be the green pesticides that will replace the synthetic pesticides, and thus, the efforts of researchers in the fields of molecular biology, biochemistry, microbiology, and environmental science are appreciable.

\section{ACKNOWLEDGEMENTS}

This research was supported by Korea Institute of Planning and Evaluation for Technology in Food, Agriculture, Forestry and Fisheries (IPET) through the Advanced Production Technology Development Program (no. 116110-2) and Export Promotion Technology Development Program (No. 617077-5), funded by the Ministry of Agriculture, Food and Rural Affairs (MAFRA), Korea.

\section{AUTHORS' CONTRIBUTION}

Yeon soo Han, Tariku Tesfaye Edosa and Young Hu Jo, generated the idea and content of the review. Tariku Tesfaye Edosa and Mariam Keshavarz conducted the literature search. Tariku Tesfaye Edosa explored the literature and wrote the paper.

\section{CONFLICT OF INTEREST STATEMENT}

The authors declare that they have no conflict of interest.

\section{REFERENCES}

1. Shekhar, S., Sundaramanickam, A. and Balasubramanian, T. 2015, Critical Reviews in Environmental Science and Technology, 45, 1522-54.

2. Hisatsuka, K-I., Nakahara, T., Sano, N. and Yamada, K. 1971, Agricultural and Biological Chemistry, 35, 686-92.

3. Chrzanowski, Ł., Stasiewicz, M., Owsianiak, M., Szulc, A. and Piotrowska-Cyplik, A. 2009, Biodegradation, 20, 661-71.

4. Arino, S., Marchal, R. and Vandecasteele, J. 1998, Journal of Applied Microbiology, 84, 769-76.

5. Vijayakuma, S. and Varatharajan, S. 2015, Research Journal of Microbiology, 10, 181-192.

6. Edwards, J. R. and Hayashi, J. A. 1965, Archives of Biochemistry and Biophysics, 111, 415-21.
7. Asselineau, C. and Asselineau, J. 1978, Progress in the chemistry of fats and other lipids, 16, 59-99.

8. Gautam, K. K. and Tyagi, V. K. 2006, J. Oleo Sci., 55, 155-66.

9. Chakrabarti, S. 2012, Bacterial biosurfactant: Characterization, antimicrobial and metal remediation properties.

10. Cavalero, D. A. and Cooper, D. G. 2003, Journal of Biotechnology, 103, 31-41.

11. Mohan, P. K., Nakhla, G. and Yanful, E. K. 2006, Water Research, 40, 533-40.

12. Nitschke, M. and Costa Sgvao. 2007, Trends in Food Science \& Technology, 18, 252-9.

13. Singh, P. and Cameotra, S. S. 2004, Trends in Biotechnology, 22, 142-6.

14. Ghribi, D., Abdelkefi-Mesrati, L., Boukedi, H., Elleuch, M., Ellouze-Chaabouni, S. and Tounsi, S. 2012, Journal of Invertebrate Pathology, 109, 183-6.

15. Mnif, I., Elleuch, M., Chaabouni, S. E. and Ghribi, D. 2013, Crop Protection, 50, 66-72.

16. Ben Khedher, S., Boukedi, H., Kilani-Feki, O., Chaib, I. and Laarif, A. 2015, Journal of Invertebrate Pathology, 132, $42-7$.

17. Ben Khedher, S., Boukedi, H., Dammak, M., Kilani-Feki, O. and Sellami-Boudawara, T. 2017, Journal of Invertebrate Pathology, 144, 11-7.

18. Mulqueen, P. 2004, Recent advances in agrochemical formulation, 106, 83-107.

19. Blackwell, P. 2000, Journal of Hydrology, 231, 384-95.

20. Nishio, E., Ichiki, Y., Tamura, H., Morita, S., Watanabe, K. and Yoshikawa, H. 2002, Bioscience, Biotechnology, and Biochemistry, 66, 1792-8.

21. Ghribi, D., Elleuch, M., Abdelkefi, L. and Ellouze-Chaabouni, S. 2012, Journal of stored products research, 48, 68-72.

22. Rostás, M. and Blassmann, K. 2009, Proceedings of the Royal Society B: Biological Sciences, 276, 633.

23. Amani, H., Mehrnia, M. R., Sarrafzadeh, M. H., Haghighi, M. and Soudi, M. R. 2010, Applied Biochemistry and Biotechnology, 162, 510-23.

24. Nihorimbere, V., Ongena, M., Smargiassi, M. and Thonart, P. 2011, Beneficial effect of the rhizosphere microbial community for plant growth and health, 15, 327-37. 
25. Arguelles-Arias, A., Ongena, M., Halimi, B., Lara, Y. and Brans A. 2009, Microbial Cell Factories, 8, 63.

26. Sutyak, K. E., Wirawan, R. E., Aroutcheva, A. A. and Chikindas, M. L. 2008, Journal of Applied Microbiology, 104, 1067-74.

27. Begley, M., Cotter, P. D., Hill, C. and Ross, R. P. 2009, Applied and Environmental Microbiology, 75, 5451-60.

28. Horowitz, S., Gilbert, J. N. and Griffin, W. M. 1990, Journal of Industrial Microbiology, 6, 243-8.

29. Morikawa, M., Ito, M. and Imanaka, T. 1992, Journal of Fermentation and Bioengineering, 74, 255-61.

30. Rosenberg, E. and Ron, E. Z. 1999, Applied Microbiology and Biotechnology, 52, 154-62.

31. Ron, E. Z. and Rosenberg, E. 2001, Natural Roles of Biosurfactants, 3, 229-36.

32. Li, X., Zhang, Y., Gulbins, E. and Da Silva M. 2010, Handbook of Hydrocarbon and Lipid Microbiology, N. T. Kenneth (Ed.), 3179-84.

33. de Lima, C. J. B., Ribeiro, E. J., Sérvulo, E. F. C., Resende, M. M. and Cardoso, V. L. 2008, Applied Biochemistry and Biotechnology, 152, 156.

34. Sarubbo, L., Do Carmo Marçal, M., Luisa, C., Neves, M., da Paz, C., Silva, M., Porto, A. and Campos Takaki, G. 2001, Bioemulsifier Production in Batch Culture Using Glucose as Carbon Source by Candida lipolytica, 95, 59-67.

35. Patil, J. R. and Chopade, B. A. 2001, Journal of Applied Microbiology, 91, 290-8.

36. Barkay, T., Navon-Venezia, S., Ron, E. and Rosenberg, E. 1999, Applied and Environmental Microbiology, 65, 2697-702.

37. Navon-Venezia, S., Zosim, Z., Gottlieb, A., Legmann, R. and Carmeli, S. 1995, Applied and Environmental Microbiology, 61, 3240-4.

38. Rosenberg, E., Rubinovitz, C., Gottlieb, A., Rosenhak, S. and Ron, E. Z. 1988, Production of Biodispersan by Acinetobacter calcoaceticus A2, 54, 317-22.

39. Cameron, D. R., Cooper, D. G. and Neufeld, R. 1988, Applied and Environmental Microbiology, 54, 1420-5.

40. Kaplan, N., Rosenberg, E., Jann, B. and Jann, K. 1985, Structural studies of the capsular polysaccharide of Acinetobacter calcoaceticus BD4, 152, 453-8.
41. Cirigliano, M. C. and Carman, G. M. 1984, Applied and Environmental Microbiology 48, 747-50.

42. Kappeli, O. and Finnerty, W. R. 1979, Journal of Bacteriology, 140, 707-12.

43. Rosenberg, E., Zuckerberg, A., Rubinovitz, C. and Gutnick, D. L. 1979, Appl. Environ. Microbiol., 37, 402-8.

44. Jadhav, M., Kalme, S., Tamboli, D. and Govindwar, S. 2011, Journal of Basic Microbiology, 51, 385-96.

45. Karanth, N. G. K., Deo, P. G. and Veenanadig, N. K. 1999, Curr. Sci. India, 77, 116-26.

46. Jarvis, F. G. and Johnson, M. J. 1949, Journal of the American Chemical Society, 71, 4124-6.

47. Ristau, E. and Wagner, F. 1983, Biotechnology Letters, 5, 95-100.

48. Suzuki, T., Tanaka, K., Matsubara, I. and Kinoshita, S. 1969, Agricultural and Biological Chemistry, 33(11), 1619-27.

49. Felse, P. A., Shah, V., Chan, J., Rao, K. J. and Gross, R. A. 2007, Enzyme and Microbial Technology, 40, 316-23.

50. Göbbert, U., Lang, S. and Wagner, F. 1984, Biotechnology Letters, 6, 225-30.

51. Cooper, D. G. and Paddock, D. A. 1983, Applied and Environmental Microbiology, 46, 1426-9.

52. Inoue, S. and Ito, S. 1982, Biotechnology Letters, 4(1), 3-8.

53. Tulloch, A. P., Hill, A. and Spencer, J. F. T. 1967, Chemical Communications (London), 12, 584-6.

54. Abraham, W-R., Meyer, H. and Yakimov, M. 1998, Biochimica et Biophysica Acta (BBA)Lipids and Lipid Metabolism, 1393, 57-62.

55. Peypoux, F., Bonmatin, J. M. and Wallach, J. 1999, Applied Microbiology and Biotechnology, 51, 553-63.

56. Richter, M., Willey, J. M., Süßmuth, R., Jung, G. and Fiedler, H-P. 1998, FEMS Microbiology Letters, 163, 165-71.

57. Kretschmer, A., Bock, H. and Wagner, F. 1982, Applied and Environmental Microbiology, 44, 864-70.

58. Kim, J-S., Powalla, M., Lang, S., Wagner, F., Lünsdorf, H. and Wray, V. 1990, Journal of Biotechnology, 13, 257-66.

59. Adamczak, M. and odzimierz Bednarski, W. 2000, Biotechnology Letters, 22, 313-6. 
60. Das, K. and Mukherjee, A. K. 2007, Process Biochemistry, 42, 1191-9.

61. Das, K., Doley, R. and Mukherjee, A. K. 2004, Biotechnology and Applied Biochemistry, 40, 291-8.

62. Mukherjee, A. K. and Das, K. 2005, FEMS Microbiology Ecology, 54, 479-89.

63. Jemil, N., Ben Ayed, H., Hmidet, N. and Nasri, M. 2016, World J. Microb. Biot., 32, 175.

64. Płaza Grażyna, A., Pacwa-Płociniczak, M., Piotrowska-Seget, Z., Brigmon, R. and Król, E. 2015, In Environmental Sustainability: Role of Green Technologies, P. Thangavel and G. Sridevi (Ed.),New Delhi: Springer India, 173-83.

65. Mnif, I. and Ghribi, D. 2015, Crop. Protection, 77, 52-64.

66. Manonmani, A., Geetha, I. and Bhuvaneswari, S. 2011, Indian Journal of Medical Research, 134, 476-82.

67. Muthusamy, K., Gopalakrishnan, S., Kochupappy Ravi, T. and Sivachidambaram, P. 2008, Current Science Association, 94(6), 736-47.

68. Daniel, H-J., Reuss, M. and Syldatk, C. 1998, Biotechnology Letters, 20, 1153-6.

69. Benincasa, M., Contiero, J., Manresa, M. and Moraes, I. 2002, Journal of Food Engineering, 54, 283-8.

70. Ghribi, D., Abdelkefi-Mesrati, L., Boukedi, H., Elleuch, M., Chaabouni Ellouz, S. and Tounsi, S. 2011, J. Invertebr. Pathol., 109(2), 183-6.

71. Anjum, F., Gautam, G., Edgard, G. and Negi, S. 2016, Bioresource Technology, 213, 262-9.
72. Raghavarao, K. S. M. S., Ranganathan, T. V. and Karanth, N. G. 2003, Biochemical Engineering Journal, 13, 127-35.

73. Robinson, T., Singh, D. and Nigam, P. 2001, Applied Microbiology and Biotechnology, 55, 284-9.

74. Pandey, A. 2003, Biochemical Engineering Journal, 13, 81-4.

75. Chung, S., Kong, H., Buyer, J. S., Lakshman, D. K. and Lydon, J. 2008, Applied Microbiology and Biotechnology, 80, 115-23.

76. Geetha, I., Manonmani, A. M. and Prabakaran, G. 2011, Acta Tropica, 120, 155-9.

77. Cheon Yun, D., Yang, S., Kim, Y., Seon Kim. I. and Hwan Kim, Y. 2013, Journal of the Korean Society for Applied Biological Chemistry, 56(6), 751-3.

78. Abd El-Salam, A., Nemat, A. M. and Magdy, A. 2011, Archives of Phytopathology and Plant Protection, 44, 204-15.

79. Das, K. and Mukherjee, A. K. 2006, Acta Tropica, 97, 168-73.

80. Geetha, I., Prabakaran, G., Paily, K. P., Manonmani, A. M. and Balaraman, K. 2007, Biological Control, 42, 34-40.

81. Ochoa-Campuzano, C., Real, M. D., MartínezRamírez, A. C., Bravo, A. and Rausell, C. 2007, Biochemical and Biophysical Research Communications, 362, 437-42.

82. BenFarhat-Touzri, D., Saadaoui, M., AbdelkefiMesrati, L., Saadaoui, I., Azzouz, H. and Tounsi, S. 2013, Journal of Invertebrate Pathology, 112, 142-5.

83. Revathi, K., Chandrasekaran, R., Thanigaivel, A., Kirubakaran, S. A., Sathish-Narayanan, S. and Senthil-Nathan, S. 2013, Pesticide Biochemistry and Physiology, 107, 369-76. 